\title{
O livro como objeto museológico
}

Oto Dias Becker Reifschneider ${ }^{\mathrm{i}}$

Resumo: Este artigo propõe o livro como objeto museológico, i.e., que sejam considerados os aspectos materiais do livro para que se entenda seu papel fulcral na sociedade. Para tanto, são elaborados três aspectos deste livro-objeto-museológico: os sociais, os materiais e os estéticos.

Palavras-chave: Livros. Museus. Bibliotecas. Objeto museológico

Abstract: The author proposes the book as a museological object, that is, its material aspects should be considered so that the book's fundamental place in society can be understood. Three aspects of this book-museological-object are dealt with: the social aspects, the material aspect and the esthetic ones.

Keywords: Books. Museums. Libraries. Museological object

Resumen: Este artículo propone el libro como objeto museológico, i.e, siendo considerados los aspectos materiales del libro para que se entienda su papel fundamental en la sociedad. Para esto, son analizados tres aspectos de este libro-objeto-museológico: los sociales, los materiales y los estéticos.

Palabras claves: Libros. Museos.Bibliotecas.Objetos museologicos. 


\section{O museu e a biblioteca}

Os museus, assim como as bibliotecas, são um dos principais propagadores da cultura contemporânea, conservando nossa história. Desde as artes plásticas, como a pintura e a escultura, até tecnologias (como a centenária imprensa e a mais recente aerospacial) e sistematizações da natureza - nas coleções de história natural - os museus guardam objetos materiais que concentram nossa reflexão sobre o mundo - os museus preservam a cultura materializada. O que importa, assim, na apreciação de um objeto museológico (uma moringa colonial, por exemplo) é o contexto social no qual ele se inseria, como e por quais razões ele era produzido, até mesmo como foi preservado, destinado a ser exposto. A função imediata, primeira, do objeto (no caso da moringa, conservar a água fresca), dá lugar a uma possibilidade de compreensão do mundo no qual vivemos, das transformações que nele ocorrem.

O livro, nas bibliotecas, é preservado e difundido prioritariamente pelo seu conteúdo. Nas coleções especiais (que preservam, entre outros, itens com forte apelo iconográfico) e nas obras raras (nestas, o fetiche pelo objeto supera muitas vezes seu valor de uso) há uma maior preocupação com o objeto. Ainda assim, a preocupação é uma de preservação, e não de compreensão da inserção do objeto "livro" na sociedade, o impacto de sua materialidade, dos processos necessários para sua feitura.

Caso se reflita sobre as características de um objeto museológico, há de se chegar rapidamente à conclusão de que todo e qualquer objeto é digno de se preservar e de ser estudado. O que diferencia algo que está em um museu - um objeto de contemplação - de algo que passa aparentemente despercebido na vida quotidiana não são qualidades intrínsecas, mas a forma como dado objeto é tratado, os olhares que são sobre ele lançados. Não há duvida, portanto, de que o livro possa não apenas ser estudado como objeto, mas que seu estudo seja central para a compreensão do desenvolvimento cultural onde quer que sua presença tenha sido sentida.

\section{O livro como objeto museológico}

O intuito deste trabalho é, como indica o título do artigo, apresentar o livro como um objeto museológico. A função primária de um texto e, portanto, do livro, é a transmissão de seu conteúdo, não importando o formato adotado. Quando nos deparamos com livros em livrarias, bibliotecas e bancos escolares, esta - a de portador de um conteúdo - é a função precípua do livro, a que nos vem em mente de forma imediata. No entanto, o interesse para além do livro-conteúdo, o livro como objeto museológico, é o enfoque particular buscado. 
Mesmo que o objeto-livro seja o mesmo de cinco séculos atrásii, a partir de sua popularização, os processos de seu fabrico passaram por diversas mudanças, que espelham as mudanças tecnológicas desde o Renascimento. Propõe-se aqui o livro como objeto museológico a ser explorado, destrinchado, por portar materialmente os traços de sua época, seja ela a dos clássicos impressores Bodoni ou a da recente revolução digital. Mesmo que fenotipicamente livros dessas duas eras não apresentem grande mudança ao olhar leigo, em suas gêneses existem enormes diferenças.

O livro, como objeto, pode ser explorado nas mais diversas vertentes que compõem a sua feitura, i.e., as técnicas, processos e materiais utilizados, devendo cada uma dessas instâncias ser situadas histórica e socialmente: melhorias nas prensas, mudanças nos tipos de papel (industrial ou artesanal), o couro (os curtiços nos quais o tratamento ele é trabalhado especificamente para encadernações), a tipografia (história de tipos distintos, a composição), as tintas, as ilustrações, as colas; as técnicas de encadernação, de gravação e ilustração, de encolamento (os papéis recebiam uma camada de cola, que passou a ser utilizada na mistura) e de costura. Poder-se-ia desenvolver uma tipologia para a classificação de livros como objetos de museu, ao se desconstruir o livro em sua materialidade ${ }^{\mathrm{iii}}$.

\section{Três aspectos do livro-objeto-museológico}

Assim como os recentes estudos sobre história da leitura, junto a pesquisas na comunicação, nas artes e na sociologia, entre outras disciplinas acadêmicas, uma exploração do livro-objeto-museológico poderia auxiliar não apenas na compreensão do papel do livro na sociedade em sua dimensão imediata de meio de conservação e propagação de cultura, memória e técnicas, mas também auxiliaria na compreensão de toda a cadeia produtiva que tem como objeto final o livro: da produção do papel à impressão e distribuição dos volumes. Outra possível conseqüência de tal pesquisa seria a promoção da leitura, algo sempre desejável em uma sociedade como a brasileira, cuja média nacional de leitura, segundo recente estudo, é de 1.3 livros por habitante/ano - excetuando-se os que freqüentam escolas ${ }^{\text {iv }}$.

Serão apresentados, a seguir, três aspectos que comportam o livro em sua materialidade: os sociais, os materiais per se e os estéticos. Espera-se que, com a aplicação desta classificação tripartite, poder-se-á analisar com mais propriedade, de forma comparativa, os elementos a serem explorados em um dado livro, para que ele receba o tratamento de um objeto museológico. 


\section{Aspectos sociais}

Um maior letramento da população, conseguido pela universalização do ensino (pós Revolução Francesa), com a implementação de redes e centros escolares, fossem eles federais, estaduais ou municipais, foi a principal mudança social que propiciou um avanço sem precedentes na edição de livros, revistas e jornais. No Brasil, tal avanço foi retardado pelo fato da edição de livros ter sido proibida durante o período colonial, além da severa restrição à circulação de obras e implementação de escolas. Após duzentos anos de implementação da imprensa no país, a situação mudou completamente. Nossa indústria do livro ${ }^{v}$ gira anualmente um capital de quase três bilhões de reais - isto sem contar o comércio de livros usados, que tem crescido em grandes centros e na internet. A Estante Virtual, o principal sítio brasileiro para venda de livros usados na internet, possui atualmente mais de quatrocentos mil leitores (compradores) e mil e duzentos livreiros cadastrados em janeiro de 2009, de todas as partes do país - totalizando mais de três milhões e setecentos mil livros disponíveis para busca imediata.

Além de condições sociais, macroeconômicas, favoráveis ao avanço do livro, foram essenciais os séculos de experimentações e melhorias na edição e impressão de obras. Os inventos do século XIX, a utilização do vapor e, posteriormente, da energia elétrica para a automatização dos parques gráficos, ou mesmo de máquinas de pequeno porte, deu um novo vulto ao empreendedorismo editorial. Conforme foi crescendo esta economia, o pessoal especializado deixou de ser formado unicamente por meio do aprendizado prático, mas também por cursos especializados. As funções foram se especializando, passando impressores, desenhistas, capistas, revisores, tradutores e outros profissionais a se formarem em cursos técnicos. Com o volume de livros impressos e uma significativa rede de livrarias e bibliotecas, a distribuição passou a ser um dos pontos fulcrais para editores e leitores: esta intermediação logística é freqüentemente feita por terceiros, cuja especialização é desdobramento do vulto tomado pela economia do livro.

\section{Aspectos materiais}

O papel talvez seja a matéria prima que primeiro se nos lembre quando pensamos em livros. Chegou ao ocidente da China, por intermédio dos árabes, no final da Idade Média. Com a rápida propagação da prensa após Gutenberg, precisou-se de material adequado e prontamente disponível para a crescente massa de livros impressos. Pergaminhos ${ }^{\mathrm{vi}}$ eram caros, a ponto de impossibilitar a impressão de livros em série, caso deles dependessem. Além disso, era matéria escassa - não existiria gado bovino, caprino ou ovino que bastasse para a produção de pergaminhos suficientes para as páginas que seriam impressas já nas primeiras 
décadas da imprensa. Para se ter uma idéia do alto custo de um livro em pergaminho (o trabalho dos copistas, obviamente, era também custoso), um mesmo volume impresso neste material era quinze vezes mais caro que outro impresso em papelvii. Houve, aliás, um recente desdobramento do estudo de pergaminhos com base em novas tecnologias: em recente notícia veiculada pela National Geographic, o DNA de pergaminhos passará a ser testado para desvendar mistérios bibliográficos, como traçar a procedência dos materiais e estabelecer datas com maior exatidão.

O papel pode ser produzido a partir de uma infinidade de fibras vegetais, tais como as de algodão, linho, bananeira, cânhamo, arroz e amoreira. Os processos para se obter papel a partir de cada uma dessas fibras naturais variam. Até o século XVIII, o papel era feito de trapo, folha por folha. A técnica desenvolvida para fazer o papel de forma contínua (como os grandes rolos produzidos pela indústria contemporânea) foi sendo aprimorada e possibilitou uma produção mais veloz e barata - foi, na verdade, com o papel obtido industrialmente (a chamada pasta química viii) que se conseguiu uma grande diminuição nos gastos. Por outro lado, ele não é tão durável, por suas fibras serem curtas e muitas vezes conter impurezas, como resíduos metálicos, que oxidam com o tempo ${ }^{i x}$. A conservação dos livros mais recentes, especialmente os impressos em meados do século XX, é uma das maiores preocupações, um dos maiores desafios de arquivistas, bibliotecários, bibliófilos e conservadores em geral.

Além do papel (e, antes, do pergaminho), para a feitura de livros são necessárias tintas. Sua composição é variável, utilizando elementos minerais e vegetais. Além da composição da tinta variar de acordo com o maquinário utilizado e o efeito desejado, cada prensa tem seu mecanismo de entintamento, i.e., de espalhar uniformemente a tinta para que a impressão seja efetuada a contento.

Para que sejam impressos os textos, já disponíveis o papel e a tinta, precisam-se também tipos ${ }^{x}$ - até que se chegasse aos atuais processadores de textos, com dezenas de fontes à escolha, houve muito estudo, muita experimentação. Existem diversas classificações dos tipos existentes. A classificação européia clássica, por exemplo, divide os tipos entre "humanistas" (aparecidos na Itália de 1460-1470), "estilo antigo" ou "old style" (variações dos humanistas de acordo com as culturas nas quais foram desenvolvidos), "transicionais" (surgiram após duzentos anos de dominação do estilo antigo), "modernos" (como Bodoni e Didot), de serifas retas, sem serifa (com origem no século XIX) e "displays" (sem origem antiga $)^{x i}$. Engana-se, contudo, quem pensa que fontes não são mais elaboradas. No Brasil, entre 1989 e 2001, foram desenvolvidas centenas de fontes digitais, conforme podemos constatar no catálogo "Fontes digitais brasileiras". Cada tipo tem sua história e tem, tradicionalmente, empregos distintos. 
Todos os insumos disponíveis são necessários ainda máquinas para impressão, além de (hoje em dia) programas de computador para tratamento do texto. As primeiras prensas utilizadas, ou prelos, eram totalmente manuais, de pressão vertical. Em seguida, foram inventados os prelos cilíndricos, mais eficientes. Os prelos eram de madeira até o início do século XIX quando, em 1807, foi inventado por Stanhope o primeiro prelo metálico - pouco tempo depois vieram os prelos a vapor ${ }^{\mathrm{xii}}$. As gráficas tinham sempre prelos de provas, para que as correções fossem feitas antes da impressão final do texto. Além das técnicas tradicionais, das técnicas gráficas (serigrafia, litografia), existem hoje a impressão a laser e a jato de tinta, entre outras.

\section{Aspectos estéticos}

Tão importantes quanto a fruição estética propiciada por elementos aparentes são os elementos estéticos "invisíveis", que nos fazem apreciar algo sem sabermos ao certo o porquê da apreciação. Entre os aparente, por exemplo, há tipos ornamentais, mais rebuscados, que são utilizados em títulos e capitulares (hoje são raras). No entanto, outras escolhas, "invisíveis", prezam por aspectos como a legibilidade que, por mais importantes que sejam, passam desapercebidos. A Times New Roman, por exemplo, foi desenvolvida especialmente para o jornal londrino The Times, por Stanley Morrison, renomado estudioso de tipografia, e Victor Lardent, designer do jornal. O resultado, segundo Vicente Gil, "contemplava o máximo de legibilidade, por meio de critérios racionais das leis oculares fundamentais, da economia de espaço e da aparência dos tipos de livros de alta qualidade."xiii Muitas das fontes hoje utilizadas são re-criações baseadas em exemplos clássicos, como aqueles elaborados pelo tipógrafo Bodoni. Os espaçamentos entre letras, entre linhas, as margens; a distribuição, enfim, o uso do branco, do vazio, para otimizar a leitura da palavra escrita é uma arte cuja importância não pode ser negada. Rubens Borba de Moraes, em seu Bibliófilo Aprendiz, admira-se da capacidade dos tipógrafos da Impressão Régia (instalada no Rio em 1808) de produzir panfletos e livros de admirável beleza tipográfica, dada a escassez de recursos.

Quanto aos processos de reprodução de imagens, a xilogravura e a calcogravura, a litografia e a serigrafia - é importante notar a relação entre uma técnica de reprodução em massa e o que é considerado artístico, ao que se dá valor como arte. As gravuras em metal e madeira, hoje valorizadas no mercado de arte, foram outrora apenas meios de reproduzir imagens (retratos, objetos, plantas arquitetônicas) em livros e revistas - o mesmo com a mais recente litografia, que teve seu auge no século XIX. Uma vez superadas estas técnicas de reprodução de imagens, elas continuam sendo utilizadas para obtenção de determinado efeito, ou mesmo apenas como forma de se preservar e enaltecer a técnica - tornam-se mais 
artísticas, menos funcionais. Toda modificação na forma de impressão pode gerar preferências, nichos, especializações, buscas. As primeiras tiragens ${ }^{\text {xiv }}$ de obras ilustradas por grandes gravuristas são, algumas vezes, procuradas não pelo texto (boa parte são traduções já superadas de obras clássicas), mas por terem impressões originais de grandes mestres da gravura brasileira ou mesmo estrangeira (como Goeldi e Axl Leskoscheck, respectivamente) não é incomum encontrar dessas impressões emolduradas, sendo os livros descartados.

Decisões estéticas permeiam a feitura do livro: na escolha da encadernação, que pode ser responsável por metade do custo do livro (há encadernações em papel, em tecido, em couro e em materiais sintéticos); caso haja sobrecapa, na forma da dobradura; na escolha da(s) fonte(s); na relação texto-imagem; no papel utilizado e no formato do livro. No entanto, estas decisões foram sempre restritas pelas técnicas vigentes, que, por sua vez, dependiam dos maquinários disponíveis: quando da impressão tipográfica, direta, utilizavam-se tipos móveis e clichês; quando do offset, a impressão era indireta; com a impressão a laser, que possibilita a impressão por demanda, multiplicam-se as possibilidades de comercialização. O advento de ebooks, os livros eletrônicos, com uma série de opções de leitura ao controle do leitor, também há de influenciar a feitura dos livros futuramente.

Quando se trata de livros engloba-se desde paperbacks, de tiragens assombrosas, em papel jornal, com curto tempo de vida - efemeridade material que muitas vezes reflete a finitude temporal do interesse em determinado conteúdo - até edições de luxo, únicas mesmo, trabalhadas página a página pelo artista. Enquanto o paperback representa o livro-conteúdo, freqüentemente com pouca sofisticação gráfica, no outro extremo encontra-se o livroexemplar-único, onde se está o mais próximo possível do livro como objeto de arte. Essa vertente do livro-arte, tão apreciada entre franceses e ingleses, é pouco explorada no país, com raras exceções, como a Cem Bibliófilos do Brasil, dirigida por Castro Maya, e os experimentos do grupo recifense $\mathrm{O}$ Gráfico Amador. Uma outra vertente exploratória do livroobjeto é a do artista plástico Waltércio Caldas, que experimenta com o formato livro desde fins da década de 1960, no início de sua carreira, até os dias de hoje, como se pode ver pelo catálogo de sua exposição “Livros", em 2000, no MAP (Museu de Arte da Pampulha).

Outro aspecto importante a ser investigado é como se dá o processo de mistificação de uma técnica, ou seja, como ela passa de um mero meio de reprodução a um fazer artístico. A princípio, o que parece acontecer é que toda revolução no setor gráfico, ao mesmo tempo em que torna um maquinário corrente e sua técnica obsoletos, dota-lhes de uma aura que apenas o que é de um tempo passado - o fazer antigo, de domínio de poucos mestres - pode ter. Este fazer é então continuado por um grupo de cultores, normalmente bons especialistas, 
que acabam por dotá-lo deste viés artístico - processo que envolve inextricavelmente o funcionamento do mercado de arte.

A arte, o design, estão obviamente (e cada vez mais) presentes em produtos massificados. Em recente conferência sobre diversos aspectos do livro (Art, fact and $\operatorname{artifact}^{\mathrm{xv}}$,Lance Hidy, conhecido designer, que iniciara seus trabalhos com livros artísticos, feitos artesanalmente, afirmou ter migrado para a indústria do livro e design para que muitos pudessem ter acesso a livros bem trabalhados, mesmo que sejam de grande circulação e a preços mais populares.

\section{Conclusões}

O livro, principal depositário da palavra escrita, permitiu a preservação e difusão do conhecimento nos últimos séculos. Além de outros meios impressos, como jornais e revistas, nos últimos anos surgiram os meios digitais, que trazem novos desafios e possibilidades, resignificando o espaço do livro. Sua importância, ao contrário de previsões pessimistas, não esmoreceu, pois o crescente letramento da sociedade vem impulsionando a indústria editorial de forma continua. Ainda que sua primazia seja superada, a importância histórica do livro é inegável, merecendo ser preservada e estudada.

Com o advento dos computadores pessoais, da internet, da popularização da cultura digital, questionou-se a palavra (fisicamente) impressa, e o objeto livro foi posto em evidência. Em determinadas áreas, é obvia a vantagem oferecida pelos meios digitais, no entanto, em se tratando de obras cujo caráter artístico dependa da materialidade, o digital não poderá tomar seu lugar. Além disso, estudos que dependam da observação de marcas no couro e no papel, da composição do objeto pela costura, da cola, da composição dos cadernos (a colação) necessitam da observação direta do estudioso. Neste caso, ferramentas eletrônicas, digitais, podem auxiliar, mas a pesquisa em primeira mão resta absolutamente primordial.

É importante ressaltar, por fim, que a proposta aqui apresentada não diz respeito apenas a obras ditas raras, especiais, ou de arte. O estudo minucioso de livros populares, muitos de baixa elaboração artística, produzidos de forma massiva e automatizada, poderá não comportar tantas minúcias estéticas e materiais quanto um livro de arte, mas os aspectos sociais, ligados à sua distribuição e consumo poderão ser mais significativos, já que mais abrangentes. As especificidades de um ou outro produto, portanto, não o desqualificam, apenas revelam aspectos constitutivos diversos. Este estudo do livro-objeto-museológico, dos processos e materiais envolvidos em seu fabrico, não significa, também, que a dimensão semântica seja esquecida, seja do texto ou da arte das ilustrações, mas o conteúdo do livro- 
objeto interessará primordialmente em relação ao aspecto material, ou aos aspectos de sua inserção social.

\section{Referências}

ABER - Associação Brasileira de Encadernação e Restauro

http://www.aber.org.br/

Art, Fact, Artifact - The Book in Time and Place

http://uicb.grad.uiowa.edu/uicb-cbaa-conference/

Estante Virtual - rede de sebos

http://www.estantevirtual.com.br/

PNLL - Plano Nacional do Livro e da Leitura

http://www.vivaleitura.com.br/pnll2/

-----. Castro Maya bibliófilo. Nova Fronteira. Rio de Janeiro, 2002.

----. Catalogo de materiaes e machinas para as artes graphicas. Leipzig. J. G. Schelter \& Giesecke, s/d.

Amorim, Galeno. Retratos da leitura no Brasil. Instituto Pró-Livro/ Imprensa Oficial. São Paulo, 2008.

Caldas, Waltercio. Livros. Museu de Arte Paulista. São Paulo, 2000.

Carroll, Rebecca. Old Books' DNA May Reveal When, Where They Were Made. 13 de janeiro de 2009.

http://news.nationalgeographic.com/news/2009/01/090113-dna-manuscripts.html

Faria, Maria Isabel e Pericão, Maria da Graça. Dicionário do livro - da escrita ao livro eletrônico. EdUSP. São Paulo, 2008.

Farias, Priscila e Piqueira, Gustavo. Fontes digitais brasileiras: de 1989 a 2001 . Edições Rosari. São Paulo, 2003.

Ferlauto, Claudio e Jahn, Heloisa. O livro da gráfica. Hamburg Gráfica Editora. São Paulo, 2001.

Frieiro, Eduardo. Os livros nossos amigos. Paulo Bluhm. Belo Horizonte, 1941.

Gil, Vicente. A Revolução dos Tipos. s/e. São Paulo, 1999.

Katzenstein, Úrsula E. A origem do livro - da Idade da Pedra ao advento da impressão tipográfica no Ocidente. HUCITEC/ Pró-Memória/ INL. São Paulo, 1986.

Mindlin, José. Uma vida entre livros. EdUSP. São Paulo, 1998.

Moraes, Rubens Borba de. $\mathbf{O}$ bibliófilo aprendiz. Briquet de Lemos/Casa da Palavra. Brasília, 2005. 
Wlasek Filho, Francisco. Os originais e a composição tipográfica. Imprensa Nacional. Rio de Janeiro, 1949.

\section{Notas}

\footnotetext{
'Bacharel em História, mestre em Sociologia, doutorando em Ciência da Informação.

ii O período dos incunábulos, da invenção de Gutenberg ao final do século XV, é considerado um de experimentações. Já no início do século seguinte, no entanto, diversas características (e mesmo algumas das fontes amplamente utilizadas nos dias de hoje) foram estabelecidas por editores-tipógrafos como Aldo Manúcio, objeto de diversos estudos acadêmicos.

iii O "Dicionário do livro" recentemente editado pela EdUSP, compilado por duas professoras portuguesas, será de extrema valia na composição de tal tipologia. Profissionais do livro (editores, gráficos, diagramadores) e manuais de diversas épocas teriam também de serem consultados. Pamfletos como Os originais e a composição tipográfica, editado em 1949 pela Imprensa Nacional, são de suma valia para se ter um conhecimento técnico de como se produzia o livro na época - são escassos tais documentos.

iv A pesquisa "Retratos da leitura no Brasil" é um importante instrumento para se avaliar o letramento no país. Seus resultados estão disponíveis não apenas em formato de livro, mas também na internet.

${ }^{\vee}$ No Brasil, que possui a oitava maior indústria do livro, segundo dados da CBL, veiculados pelo PNLL, foram vendidos 310 milhõ es de exemplares, totalizando 2,9 bilhões de reais. A estadunidense, a maior potência do livro, gira um valor aproximadamente cinco vezes maior que o brasileiro.

vi Produzidos a mais de dois mil anos, os pergaminhos são assim denominados por terem sido amplamente difundidos a partir de Pérgamo. É importante ressaltar que o pergaminho é obtido por meio de uma técnica específica, não de um único tipo de couro.

vii Dicionário do livro, p. 548, "papel"

viii Este processo foi inventado em 1846, ocorrendo a partir da maceração de madeiras e outros vegetais (Dicionário do livro, p. 551 , "papel de pasta química")

${ }^{\text {ix }}$ Além das fibras serem mais curtas, elas são tratadas de forma agressiva, restando dilaceradas. Ademais, a lignina, componente da madeira, quando não extraída apropriadamente leva à rápida deterioração dos papéis.

“ "Tipos" e "fontes" podem ser utilizados de maneira intercambiável quando nos referimos a impressos. Em meios digitais, utilizase apenas o segundo termo.

xi O livro da gráfica, p. 11

xii Dicionário do livro, p. 592, "prelo manual" e "prelo Stanhope".

xiii GIL, p. 104

xiv Em tiragens posteriores, as matrizes de xilogravura eram substituídas por clichês, pois elas não agüentariam o desgaste de sucessivas impressões.

${ }^{x v}$ Esta conferência, sediada na Universidade de lowa, que possui um centro de estudos do livro, ocorreu em janeiro de 2009 e assinalou o nascimento da CBAA - College Book Art Association.
} 